\title{
Estudos e movimentos sobre Fundamentos da Educação
}

\author{
Estudios y movimientos en Fundamientos de la Educación
}

\author{
${ }^{1}$ Richard Mendes da Costa; ${ }^{2}$ Marília Sheila dos Santos; ${ }^{3}$ Larissa de Oliveira Pedra; ${ }^{4}$ Dra. \\ Neiva Afonso Oliveira; ${ }^{5}$ Dra. Heloisa Helena Duval de Azevedo \\ ${ }^{1}$ Universidade Federal de Pelotas ; ${ }^{2}$ Universidade Federal de Pelotas; ${ }^{3}$ Universidade federal \\ de Pelotas; ${ }^{4}$ neivaafonsooliveira@ @mail.com, Universidade Federal de Pelotas; \\ 5profa.heloisa.duval@gmail.com, Universidade Federal de Pelotas.
}

\begin{abstract}
Resumo
O trabalho faz parte de um projeto de ensino intitulado Audioaulas, captura de tela e videoaulas para aulas de Fundamentos Sócio-Histórico-Filosóficos da Educação ligado a um projeto de pesquisa mais encorpado, intitulado $O$ viés da linguagem para pensar a interatividade e a aprendizagem colaborativa na modalidade a distância na/da UFPEL. Com o objetivo de desenvolver material didático para a disciplina de Fundamentos Sócio-Histórico-Filosóficos da Educação, utilizamos como metodologia recursos multimídias para auxiliar na motivação da aprendizagem, do esclarecimento e do aprofundamento do conteúdo. Além da pesquisa bibliográfica e encontros entre orientadora e bolsistas, o que motivou a mudança de rumo do projeto de ensino tornando-o um tensionador entre as fronteiras das disciplinas da área de Fundamentos de Educação por meio da realização de um documentário resgatando/conhecendo/reconhecendo as trajetórias das disciplinas e conteúdos já trabalhados pelos docentes que, nos últimos 39 anos, "deram o tom” aos Fundamentos da Educação na FaE (Faculdade de Educação) e nos cursos de Licenciatura da UFPel - será feito o resgate da memória entre os atingidos pela disciplina (docentes e discentes). A pesquisa encontra-se em fase de coleta das entrevistas com cinco docentes que estão ou estarão aposentados até o final do ano de 2015.
\end{abstract}

Palavras-chave: Fundamentos Sócio-Histórico-Filosóficos da Educação, Filosofia da Educação, História da Educação, Documentário.

\section{Introdução}

O trabalho é fruto do projeto de ensino intitulado Audioaulas, captura de tela $e$ videoaulas para aulas de Fundamentos Sócio-Histórico-Filosóficos da Educação ligado a um projeto mais encorpado de pesquisa, intitulado $O$ viés da linguagem para pensar a interatividade e a aprendizagem colaborativa na modalidade a distância na/da UFPEL. Parte da necessidade de compreender os objetivos adotados como ideais no ensino das disciplinas de Fundamentos da Educação: Filosofia da Educação, História da Educação e Fundamentos Sócio-Histórico-Filosóficos da Educação na UFPel. Uma reflexão sobre a educação, entendida aqui como processo de formação humana, requer exame aprofundado no campo de atividade das disciplinas citadas buscando ver quais os significados e desenhos que essa formação recebeu ao longo de nossa tradição histórico-filosófica e na contemporaneidade.

Considerando o universo de pesquisa, constatamos que aconteceram mudanças nas concepções que os homens fizeram do ideal de sua humanização clamando por um redirecionamento das metodologias de compreensão da realidade. Sob tal perspectiva, é necessário retomar a discussão a respeito das relações entre os diversificados âmbitos da educabilidade humana, não só destacando as perspectivas éticas e políticas que, até o atual momento, permaneceram como fundamentos da compreensão da própria natureza da educação, mas também avançando em direção à descoberta de novas epistemologias 
educativas levando em conta que, hoje, a formação humana, visada pela educação, compreende-se como formação cultural geral. Isso nos motivou à aventura que nos joga para teorizar sobre os limites fronteiriços das disciplinas que envolvem a área de Fundamentos da Educação bem como para a realização de um primeiro documentário que resgatará brechas de memória da instituição.

\section{Desenvolvimento}

Um dos objetivos do projeto de ensino foi o de desenvolver material de apoio aos docentes do grupo de pesquisa EADEM e FEPráxiS da FaE/UFPel e que trabalham com a disciplina Fundamentos Sócio-Histórico-Filosóficos da Educação. A ideia inicial consiste no desenvolvimento de material audiovisual com conteúdo didático e audiovisual produzido com técnicas de animação em flash e captura de tela sobre o caminho da educação ao longo da história da $\mathrm{FaE}$, visando ampliar o interesse dos discentes e gerar mais "gatilhos" para o trabalho da disciplina em sala de aula, como também disponibilizar o material de apoio a ser consultado além do período de aula.

Originalmente, a ideia era a de apresentar dois personagens atuais que viajam no tempo e encontram-se com importantes filósofos para aprender sobre educação e filosofia em cada época e região. Como inspiração inicial, Heráclito, Protágoras e Platão foram conclamados. Consideramos um estímulo não só para os discentes como para os docentes a utilização das TICs (Tecnologia da Informação e Comunicação).

Nas reuniões entre os bolsistas e a orientadora, o trabalho tomou outro rumo indo ao encontro das inquietações apresentadas de forma incipiente no grupo e em ressonância com fóruns nacionais e internacionais que tratam da relação entre educação e filosofia. Considerando a literatura que trata da educação, é fato que desde a década de 1970 mencionase a crise da educação. Hannah Arendt, em sua obra intitulada Entre o Passado e o Futuro, inquieta seus leitores dizendo que a educação americana estava em crise desde os anos de 1960. A partir dessa obra que reverbera até hoje, falamos em crise na educação.

Nessa mudança de rumo, um dos vários questionamentos do grupo foi o fato de acreditar que as práticas mostram a estagnação de um modelo de ensino que não atinge ou sensibiliza os acadêmicos em prol de uma discussão tão necessária. São práticas ambíguas, ao propor uma crítica à educação que não se aplica à sua própria atuação pedagógica. Mas há que se imaginar o que se passa na realidade de atuação deste docente, pois o que vê, hoje, tem todo um significado próprio para olhos que já viram as disciplinas de Fundamentos de Educação sendo efetivadas como instrumento de luta contra a opressão, aproveitando safras de estudantes que, de uma forma paradoxal, só eram discentes ideais porque foram forjados em sistemas de ensino ditos opressores que ajudaram a repensar e a desconstruir.

No que se refere aos Fundamentos da Educação, trata-se de afirmarmos que não é apenas teoria. Esta e a prática devem ter vínculos e ligações que se caracterizam pelo fato de a teoria dirigir ou orientar/guiar a prática - a prática da reflexão crítica. Orientar-se tão só pela prática resulta em “... confusão e contradição.” (Niskier, 2001, p. 38). A teoria explica os fatos, a prática dedica-se a um movimento de decisão sobre o que fazer com tais fatos e ao modo como juntá-los a valores educacionais.

A mudança de rumo exigiu estreitar os limites, as fronteiras entre as áreas que compõem os Fundamentos da Educação: Filosofia, História, Psicologia e Sociologia; resgatando a memória dessas disciplinas na instituição. Invocando a deusa Mnemosyne, optou-se pelo desenvolvimento de um projeto/documentário que versa sobre o trajeto da disciplina em foco ao longo do tempo e com destaque para os nomes que intermediaram essa andarilhagem. O documentário, em fase de gravação das entrevistas, trata da história regional da FaE (Faculdade de Educação) e consolidação da disciplina de Fundamentos Sócio- 
Histórico-Filosóficos da Educação e da Filosofia da Educação na UFPel através dos olhos de antigos e importantes docentes da universidade.

As entrevistas principais ocorrem com seis docentes e são intercaladas e debatidas com discentes e outros docentes da Universidade visando apontar detalhes históricos relacionados à disciplina com pontos de vista pessoais críticos sobre os Fundamentos da Educação e correlacionando-os com uma visão que abrange o cenário nacional e internacional.

\section{Conclusões}

As perguntas trabalhadas no roteiro juntamente com a preparação do personagem para a entrevista direcionam o entrevistado por um caminho que induz à busca por informações e sentimentos verdadeiros que são captados por câmera e microfones, acompanhados de planos ilustrativos gravados e apresentados juntamente com imagens de arquivo que ilustram a verdade dita em cena. Comporão um material rico não só em informação, mas também em apelo emocional e relevância cinematográfica as matérias capturadas.

Uma das referências utilizadas para a construção do roteiro em prol do efeito em público é o trabalho que a cineasta brasileira Petra Costa conseguiu realizar em 2012 com o documentário Elena, em que busca reforçar aspectos históricos do assunto tratado não só com imagens de arquivo, mas também com captura de material encenado, o que reforça a verdade dita em tom poético e atrativo.

O documentário também terá exibição na sala de aula com intuito de reforçar a conexão entre os discentes e a disciplina, ajudando a criar um ambiente mais propício para os docentes e mais agradável a recepção de conteúdo por parte dos discentes.

$\mathrm{E}$, eis que no emaranhado de reflexões e inquietações compartilhadas, desvela-se nossa questão central, este mal-estar que nos une e afasta ao nos assombrar, a cada semestre letivo: estamos cumprindo com a exigência de nossa práxis? Não estamos promovendo, no ambiente acadêmico, certos condicionamentos desde esse mal-estar? Essas questões exigem um posicionamento que, partindo da necessidade de invenção e inovação para pensar/repensar a relação entre teoria e prática na sala de aula precisa, sem dúvida, pensar a formação dos professores das disciplinas dos Fundamentos da Educação.

\section{Referências}

ARENDT, Hannah. Entre o Passado e o Futuro. São Paulo: Editora Perspectiva, 2001.

NISKIER, Arnaldo. Filosofia da educação: uma visão crítica. São Paulo: Loyola, 2001. 